\title{
\#USGS
}

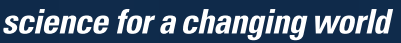

\section{Preliminary Peak Stage and Streamflow Data at Selected USGS Streamgaging Stations for the \\ South Carolina Flood of October 2015}
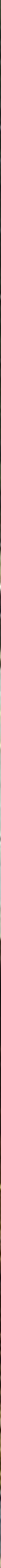

Open-File Report 2015-1201

Version 1.1, November 2015

U.S. Department of the Interior

U.S. Geological Survey 



\section{Preliminary Peak Stage and Streamflow Data at Selected USGS Streamgaging Stations for the South Carolina Flood of October 2015}

By Toby D. Feaster, John M. Shelton, and Jeanne C. Robbins

Open-File Report 2015-1201

Version 1.1, November 2015 


\title{
U.S. Department of the Interior SALLY JEWELL, Secretary
}

\section{U.S. Geological Survey Suzette M. Kimball, Acting Director}

\author{
U.S. Geological Survey, Reston, Virginia: 2015 \\ Revised: November 2015
}

\begin{abstract}
For more information on the USGS - the Federal source for science about the Earth, its natural and living resources, natural hazards, and the environment—visit http://www.usgs.gov or call 1-888-ASK-USGS.

For an overview of USGS information products, including maps, imagery, and publications, visit http://www.usgs.gov/pubprod/.
\end{abstract}

\author{
Any use of trade, firm, or product names is for descriptive purposes only and does not imply endorsement by the \\ U.S. Government. \\ Although this information product, for the most part, is in the public domain, it also may contain copyrighted materials \\ as noted in the text. Permission to reproduce copyrighted items must be secured from the copyright owner. \\ Suggested citation: \\ Feaster, T.D., Shelton, J.M., and Robbins, J.C., 2015, Preliminary peak stage and streamflow data at selected \\ USGS streamgaging stations for the South Carolina flood of October 2015 (ver. 1.1, November 2015): U.S. Geological \\ Survey Open-File Report 2015-1201, 19 p., http://dx.doi.org/10.3133/ofr20151201. \\ ISSN 2331-1258 (online)
}




\section{Contents}

Abstract
Introduction.
Purpose and Scope
Study Area
General Weather Conditions and Precipitation That Contributed to the 0ctober 2015 Flooding
Peak Streamflow and Stage
Comparison of the October 2015 Flood to Past Floods
Summary

\section{Figures}

1. Infrared satellite image of the intense rainfall being funneled into South Carolina during the morning of October 3, 2015 .

2. Aerial photograph of flooding in Columbia, S.C., at the confluence of the Broad and Saluda Rivers, looking upstream.........................................................................

3. Aerial photograph of flooding in Charleston, S.C., and surrounding areas,

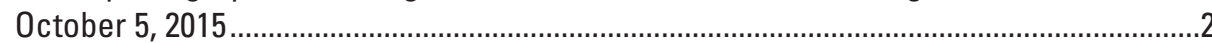

4. Image showing preliminary National Weather Service rainfall totals for

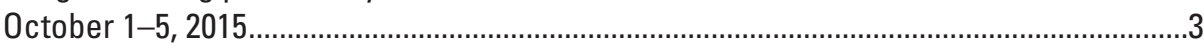

5. Graph showing Black River at Kingstree, S.C. (USGS station 02136000), total rainfall for October 1-5, 2015.............................................................................................

6. Map showing USGS real-time streamgages in South Carolina ........................................

7. Photograph showing USGS personnel making a streamflow measurement at station 02110701, Crabtree Swamp at Conway, S.C., using an acoustic Doppler current profiler....

8. Rating curves developed for use before (red) and after (blue) the October 2015 flood for Bush River near Prosperity, S.C. (USGS station 02167582) showing streamflow measurements made during the event

9. Photograph showing USGS field crews conducting surveys of high-water marks to document the depth of flood waters in Lexington County, S.C., for the October 2015 flood

10. Black River at Kingstree, S.C. (USGS station 02136000) stage and streamflow hydrographs and graph showing associated rainfall for October 1-11, 2015

\section{Tables}

1. Preliminary peak stage and streamflow data at selected streamgages in South Carolina for the October 2015 flood.

2. Chronology of major and other memorable floods in South Carolina since 1893 ............19 


\section{Conversion Factors}

\begin{tabular}{|c|c|c|}
\hline Multiply & By & To obtain \\
\hline \multicolumn{3}{|c|}{ Length } \\
\hline foot (ft) & 0.3048 & meter $(\mathrm{m})$ \\
\hline mile (mi) & 1.609 & kilometer (km) \\
\hline \multicolumn{3}{|c|}{ Area } \\
\hline square mile $\left(\mathrm{mi}^{2}\right)$ & 259.0 & hectare (ha) \\
\hline \multirow[t]{2}{*}{ square mile $\left(\mathrm{mi}^{2}\right)$} & 2.590 & square kilometer $\left(\mathrm{km}^{2}\right)$ \\
\hline & Flow rate & \\
\hline foot per second $(\mathrm{ft} / \mathrm{s})$ & 0.3048 & meter per second $(\mathrm{m} / \mathrm{s})$ \\
\hline cubic foot per second $\left(\mathrm{ft}^{3} / \mathrm{s}\right)$ & 0.02832 & cubic meter per second $\left(\mathrm{m}^{3} / \mathrm{s}\right)$ \\
\hline
\end{tabular}




\title{
Preliminary Peak Stage and Streamflow Data at Selected USGS Streamgaging Stations for the South Carolina Flood of October 2015
}

\author{
By Toby D. Feaster, John M. Shelton, and Jeanne C. Robbins
}

\begin{abstract}
Heavy rainfall occurred across South Carolina during October 1-5, 2015, as a result of an upper atmospheric low-pressure system that funneled tropical moisture from Hurricane Joaquin into the State. The storm caused major flooding from the central to the coastal areas of South Carolina. Almost 27 inches of rain fell near Mount Pleasant in Charleston County during this period. U.S. Geological Survey streamgages recorded peaks of record at 17 locations, and 15 other locations had peaks that ranked in the top 5 for the period of record. During the October 2015 flood event, U.S. Geological Survey personnel made about 140 streamflow measurements at 86 locations to verify, update, or extend existing rating curves, which are used to compute streamflow from monitored river stage.
\end{abstract}

\section{Introduction}

The presence of an upper atmospheric low-pressure system over the Southeast funneled tropical moisture from Hurricane Joaquin into South Carolina during the period October 1-5, 2015, causing historic rainfall amounts (http://www.weather.com/news/news/stunning-meteorologicalimages-october-2015-flooding, accessed October 8, 2015) (fig. 1). Widespread, heavy rainfall resulted in major flooding in areas from the central part of the State (fig. 2) to the coast (fig. 3). Some areas experienced more than 20 inches of rainfall over the period October 1-5, 2015 (fig. 4; National Weather Service, written commun., October 7, 2015). One USGS raingage at Black River at Kingstree, South Carolina (USGS station 02136000), recorded 22.89 inches of rain for the period October 1-5, 2015 (fig. 5). Flooding from

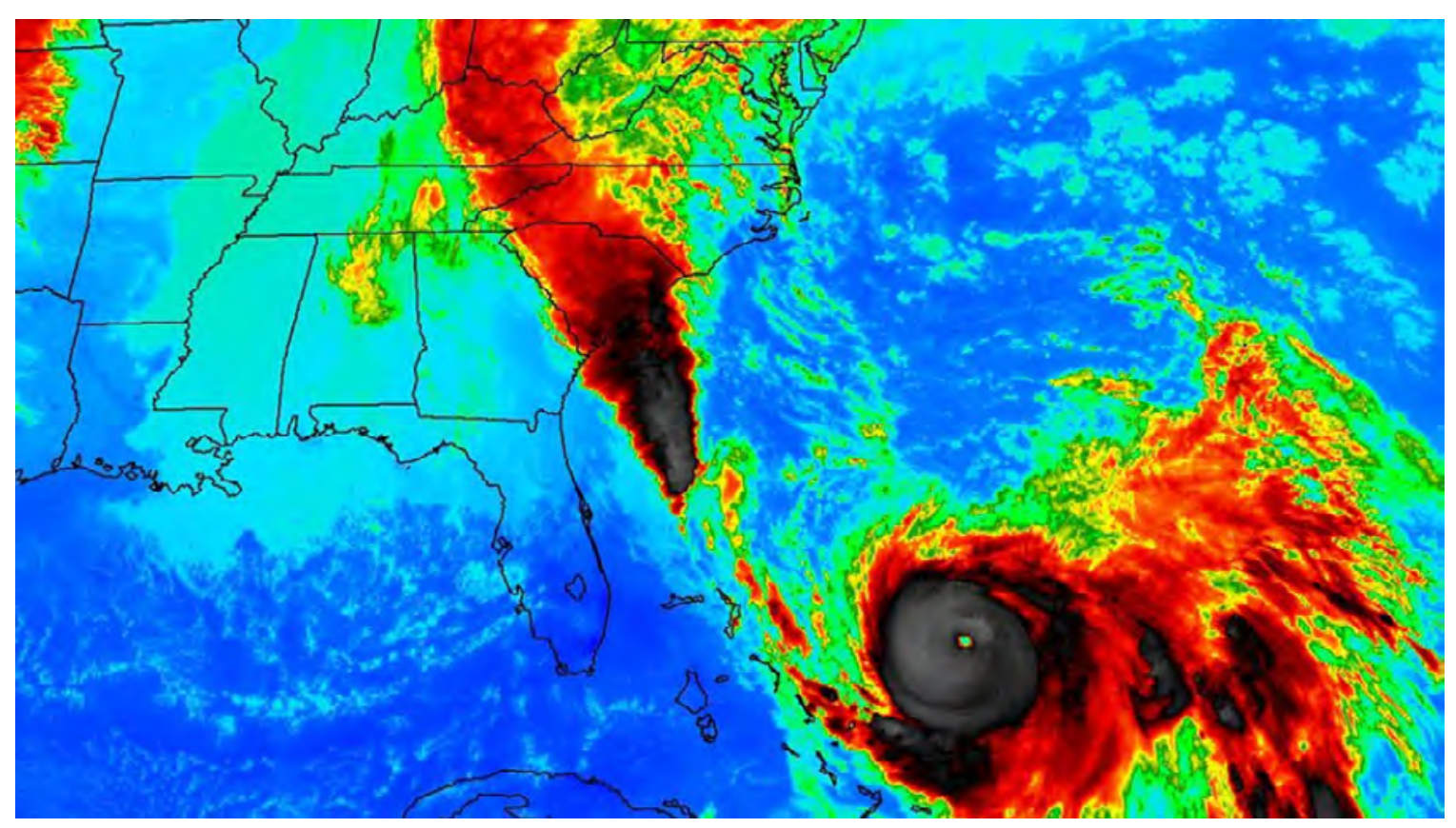

Figure 1. Infrared satellite image of the intense rainfall being funneled into South Carolina during the morning of October 3, 2015. (NASA) 


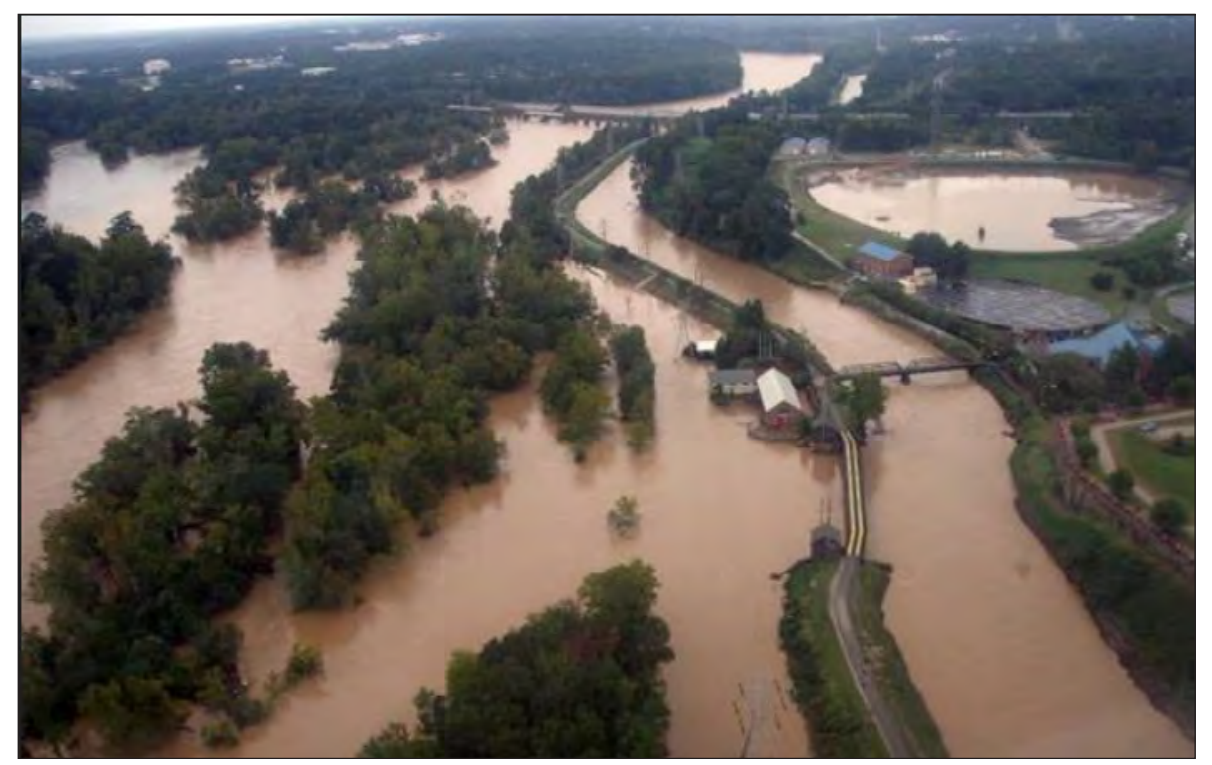

Figure 2. Aerial photograph of flooding in Columbia, South Carolina, at the confluence of the Broad and Saluda Rivers, looking upstream. (Photograph by the South Carolina Army National Guard, October 5, 2015)

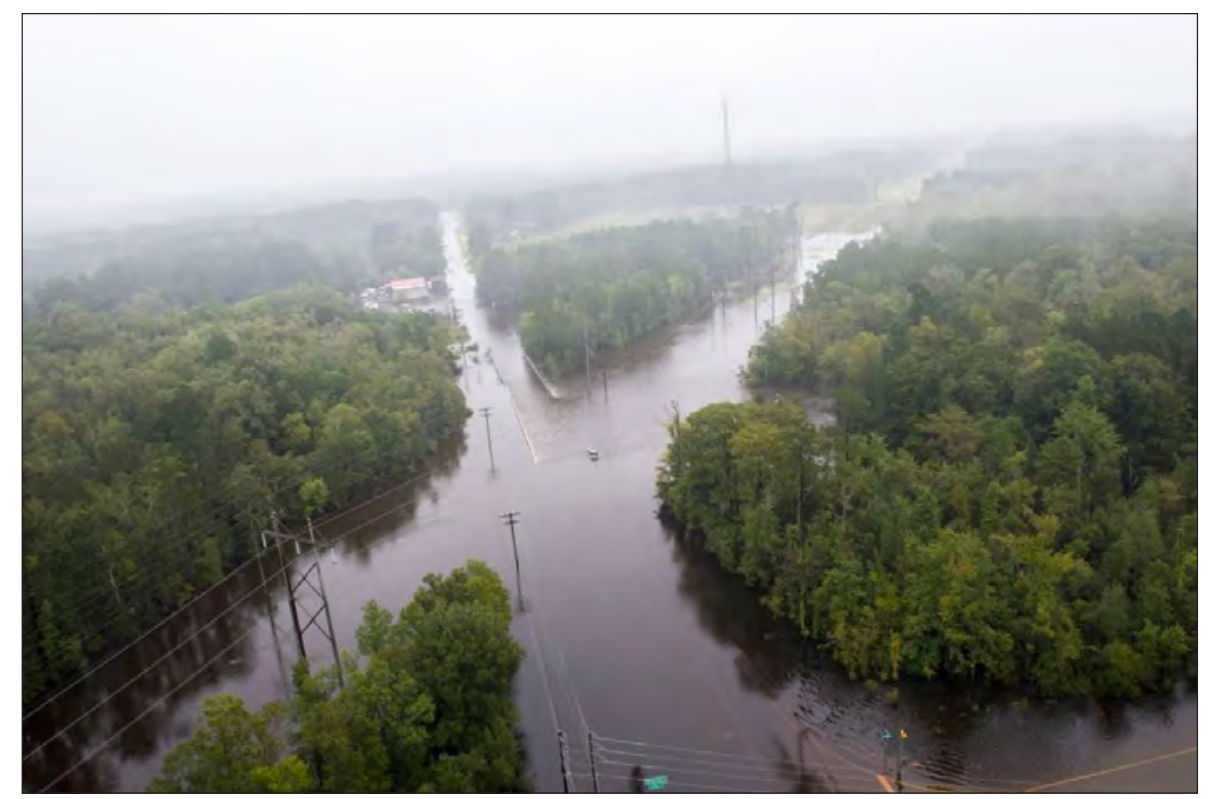

Figure 3. Aerial photograph of flooding in Charleston, South Carolina, and surrounding areas, October 5, 2015. (Photograph by Petty Officer 1st Class Stephen Lehmann, U.S. Coast Guard) 


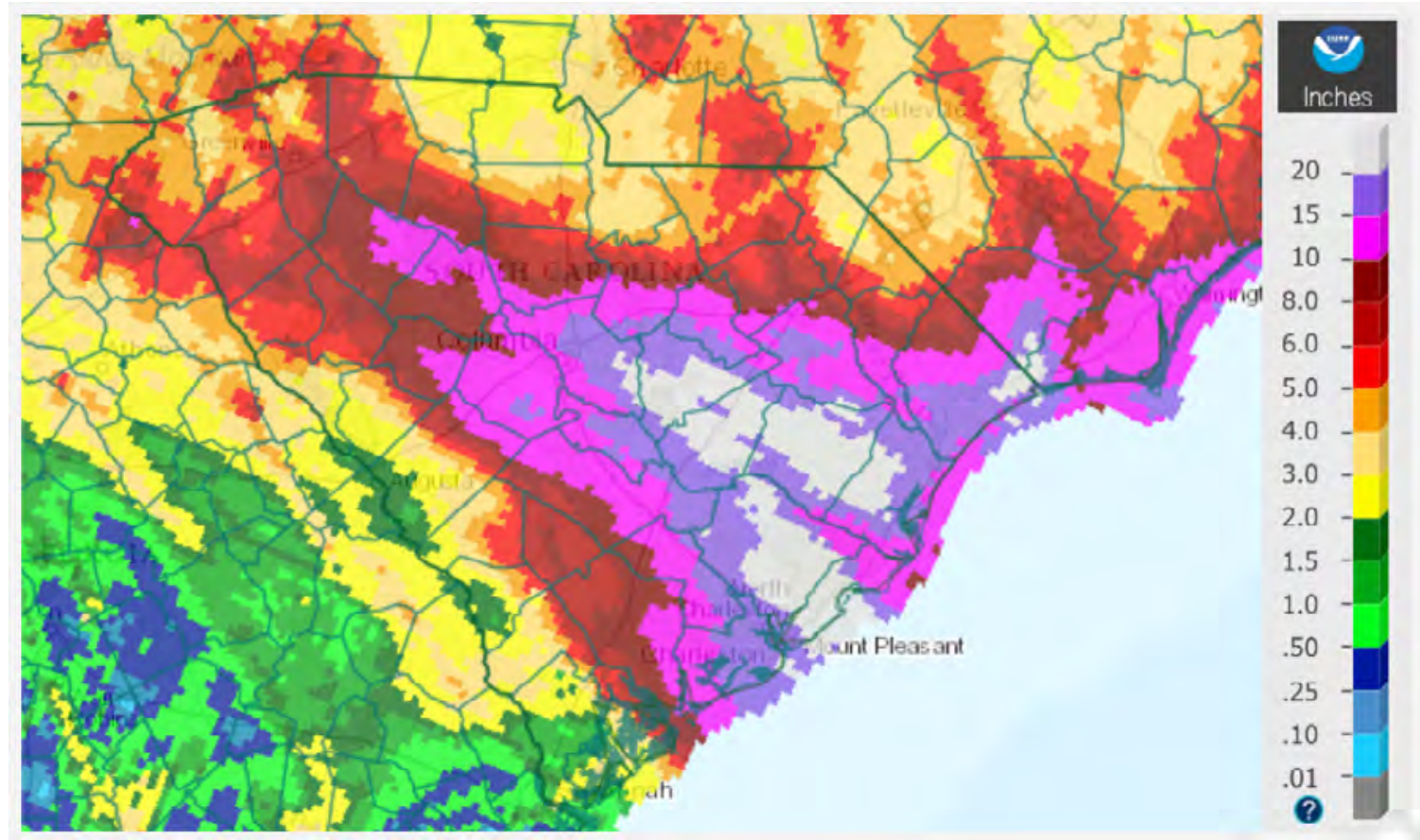

Figure 4. Preliminary National Weather Service rainfall totals for October 1-5, 2015. (National Weather Service)

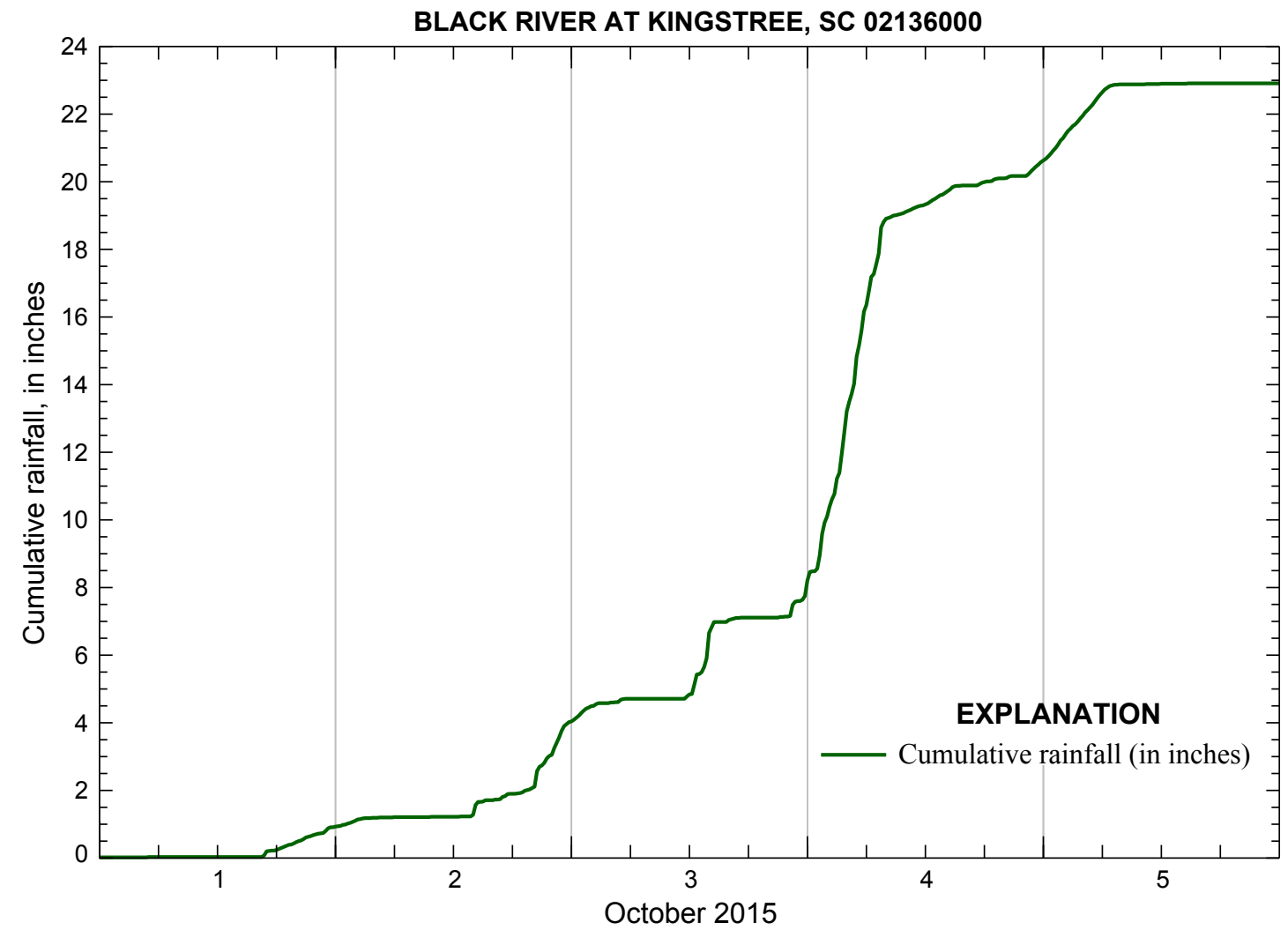

Figure 5. Black River at Kingstree, South Carolina (U.S. Geological Survey station 02136000), cumulative total rainfall for October 1-5, 2015. 
this event resulted in at least 17 fatalities (http://www. reuters.com/article/2015/10/07/us-usa-weather-floodsidUSKCN0S11E720151007, accessed October 8, 2015). South Carolina officials have been quoted in media outlets as saying agricultural losses could conservatively be at least $\$ 300$ million, with cleanup costs across the State that could top $\$ 1$ billion (http://www.latimes.com/nation/la-na-southcarolina-postcards-20151008-htmlstory.html, accessed October 9, 2015).

The U.S. Geological Survey (USGS) collects and disseminates streamflow data at more than 9,800 streamgages nationwide. In South Carolina, the USGS operates about 170 real-time streamgages, in cooperation with numerous local, State, and Federal agencies, monitoring gage height, streamflow, reservoir elevations, and tidal flow (fig. 6; http:// waterdata.usgs.gov/sc/nwis/current/?type=flow). Streamflow data collection serves a variety of purposes including providing information for flood forecasts and documenting flood extent and levels. Leading up to and during flooding, streamflow data are vital for flood warning, forecasting, and emergency management. The long-term, systematic streamflow data are used to assess risk and to mitigate flooding through flood-plain management and in the design or repair of infrastructure (for example, roads, bridges, reservoirs, and pipelines), houses, and buildings.

\section{Purpose and Scope}

The purpose of this report is to provide preliminary information documenting the peak streamflows and stages for those rivers and streams in South Carolina that are part of the USGS real-time streamgaging network impacted by the historic rainfall that occurred October 1-5, 2015. The 2015 flood peak flows are placed into context by ranking the October 2015 flood peaks with other annual flood peaks for the period of record at each streamgage as well as historic floods that might precede USGS systematic records. National Weather Service (NWS) flood stage information is also provided for sites where a NWS flood stage has been defined (table 1, at the back of the report).

\section{Study Area}

South Carolina is located on the South Atlantic slope adjacent to the Atlantic Ocean, has an area of 31,055 square miles, and is generally divided into three major physiographic provinces: Blue Ridge, Piedmont, and Coastal Plain (Cooke, 1936). The Blue Ridge is a mountainous region of steep terrain with some stream gradients greater than 250 feet (ft) per mile (Bloxham, 1979). Land-surface elevation ranges from 1,000 to more than 3,500 ft above sea level.

The Piedmont is characterized by rolling hills, elongated ridges, and moderately deep to shallow valleys. Piedmont land-surface elevations range from about $1,000 \mathrm{ft}$ above sea level at the Blue Ridge foothills to about $400 \mathrm{ft}$ above sea level at the Fall Line, which is the name given to the boundary between the Piedmont and Coastal Plain regions.
About two-thirds of the State is in the Coastal Plain region (Badr and others, 2004). In the Coastal Plain, bedrock is overlain by sediments, which thicken from just a few feet near the Fall Line to about 3,800 feet at the southernmost corner of the State. At the Fall Line, a narrow, hilly region, known as the Sand Hills, is located where the Piedmont descends to the Coastal Plain (National Oceanic and Atmospheric Administration, 2015). The Sand Hills region is about 30 to 40 miles wide with elevations ranging from about 500 to 200 feet. The lower part of the Coastal Plain consists of low-elevation, flat plains with many swamps, marshes, dunes, barrier islands, and beaches, which typically are lower, flatter, and more poorly drained than the upper part of the Coastal Plain (Omernik, 1987).

In South Carolina, precipitation is principally delivered by storms that move inward from the Gulf of Mexico, the Caribbean Sea, and the Atlantic Ocean (U.S. Geological Survey, 1985). Additionally, local and upwind land surfaces, as well as lakes and reservoirs, provide moisture to the atmosphere by evaporation. In a normal year, monthly precipitation is highest in the winter, reaching a maximum in early March and then decreasing sharply in April and May. Annual rainfall in South Carolina averages as much as 80 inches in the highest elevations of the Blue Ridge to less than 45 inches in parts of the upper portion of the Coastal Plain and Sand Hills regions (National Oceanic and Atmospheric Administration, 2015). In general, the Blue Ridge region receives an average of about 56 inches or more of annual rainfall, the upper portion of the Piedmont about 47 to 55 inches, the lower portion of the Piedmont about 45 to 48 inches, the upper portion of the Coastal Plain about 44 to 49 inches, and the lower portion of the Coastal Plain about 46 to 53 inches. Fall is typically a dry season (except in instances when tropical cyclones occur) with minimal statewide precipitation during October and November.

\section{General Weather Conditions and Precipitation That Contributed to the October 2015 Flooding}

The combination of a slow-moving, upper-level low over the Southeastern United States, an area of low pressure at the surface located along a stationary frontal boundary, and a persistent plume of tropical moisture associated with Hurricane Joaquin (fig. 1) produced historic rainfall over portions of South Carolina during the period October 1-5, 2015 (L. Vaughn, National Oceanic and Atmospheric Administration, written commun., October 8, 2015). This system caused significant widespread freshwater flooding throughout the State. Preliminary data show the highest rainfall total of 26.9 inches near Mount Pleasant, S.C. (Charleston County) (fig. 4). Preliminary data also show the Charleston Airport rainfall totals set new records for the 


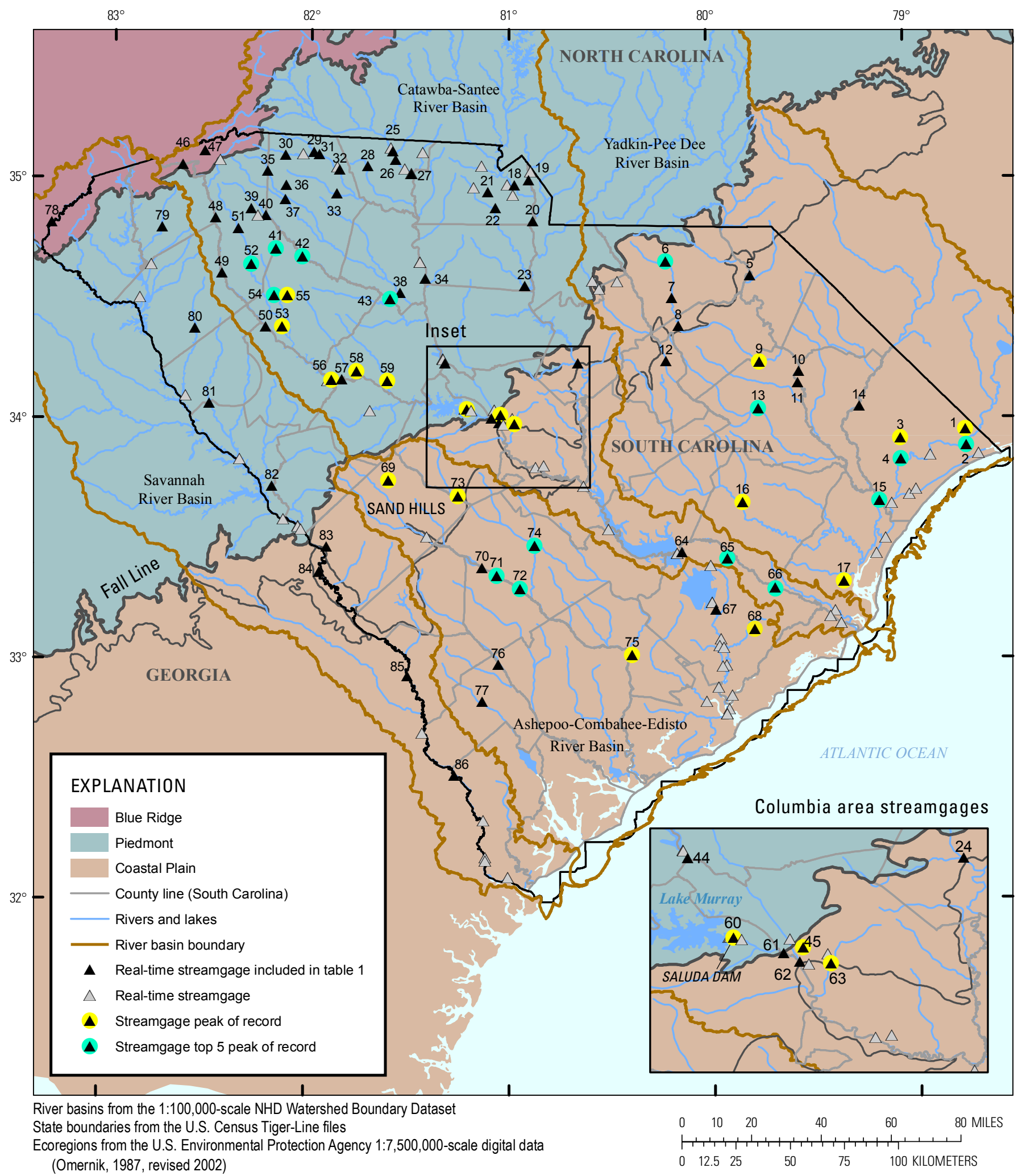

Figure 6. USGS real-time streamgages in South Carolina. 
greatest 1-, 2-, 3-, and 4-day totals of 11.50, 14.31, 15.92, and 17.29 inches, respectively (National Weather Service, written commun., October 5, 2015). The previous record totals were 10.52 inches on September 21, 1998; 11.10 inches on June 10-11, 1973; 11.95 inches on June 9-11, 1973; and 16.56 inches on June 7-11, 1973. The downtown Charleston rainfall for October 3, 2015, was the third highest 1-day total rainfall of 9.25 inches with the highest 1-day total rainfall of 10.38 inches occurring on June 11, 1973; October 3-4, 2015, was tied for the highest 2-day total rainfall of 11.74 inches, which occurred on June 10-11, 1973; October 1-3, 2015, set a new record for the greatest 3-day total rainfall of 13.80 inches with the previous high being 12.39 inches on June 9-11, 1973; and October 1-4, 2015, set a record for the greatest 4-day total rainfall of 16.29 inches with the previous high being 13.80 inches on June 7-11, 1973. The Columbia Metropolitan Airport rainfall on October 4, 2015, set a new record for the greatest 1-day rainfall of 6.71 inches, breaking the previous record of 5.79 inches set on July 9, 1959. In addition, the October 3-4, 2015, rainfall set a new record for the greatest 2-day rainfall at the airport of 10.28 inches, breaking the previous record of 7.69 inches on August 16-17, 1949, (http://www.weather.gov/cae/HistoricFloodingOct2015.html, accessed October 13, 2015). The historic rainfall also resulted in moderate to major river flooding at selected NWS river forecast points across South Carolina. At least 20 NWS river forecast locations exceeded established NWS flood stages (table 1).

The impacts of this event were widespread across South Carolina. Approximately 410 roads or bridges were closed during the event including 74 miles of I-95 between I-26 and I-20 (U.S. Department of Interior Office of Emergency Management, written commun., October 8, 2015). At least 17 minor dam failures resulted from the rainfall event. Some major reservoirs, such as the Saluda Dam at Lake Murray, initiated flood control releases. South Carolina emergency management officials reported that more than 200 water rescues were conducted. In addition to flooding, saturated soils along with moderate to strong east/northeasterly winds contributed to the downing of trees and power lines across portions of South Carolina. As a result, about 50,000 residents lost power during the storm as of Monday, October 5, 2015 (L. Vaughn, National Oceanic and Atmospheric Administration, written commun., October 8, 2015).

\section{Methods Used to Collect Stream- flow Data}

In this report, streamflow data refer to both stage or gage height (in feet) and volumetric streamflow (in cubic feet per second). These data were collected systematically at continuous record streamgages or from field measurements of stage in cases where the gage structure or equipment was damaged by flood waters.

U.S. Geological Survey streamgages operate autonomously by collecting data at regular time intervals (typically either 5 or 15 minutes) depending on watershed size and flashiness of the stream. Typically, streamgages automatically record stage data. The stage data are collected using a variety of methods (float, submersible pressure transducer, non-submersible pressure transducer, or non-contact radar). More information about how USGS streamgages work is available in Lurry (2011). Although stage data are important, streamflow data are often more important for such purposes as streamflow forecasting for flood warning, water-quality loading, flood-frequency analysis, and flood-mitigation planning. Computation of streamflow at a streamgage requires periodic measurements of streamflow over a range of stage. The relation defined between stage and measured streamflow is used to convert the stage data to streamflow. USGS personnel (fig. 7) measure stream velocity and stream depth onsite to determine near-instantaneous streamflow (Turnipseed and Sauer, 2010).

In most cases, the correlation is a simple stagestreamflow relation or rating curve. After construction of the rating curve, continued periodic measurements of streamflow are required at various stages to verify or support changes to a station rating curve. (fig. 8). During the October 2015 flood, USGS personnel made about 140 streamflow measurements at 86 locations in South Carolina to verify, update, or extend existing rating curves.

In some cases, direct measurements of streamflow during a flood are not possible or are impractical. In those instances, indirect measurement methods can be used (Benson and Dalrymple, 1967), whereby water-surface profiles determined by high-water marks and channel roughness and geometry are used in hydraulic equations based on the principles of conservation of energy, conservation of momentum, and continuity to compute the peak streamflow for that particular flood. The high-water marks and channel geometry are determined by 


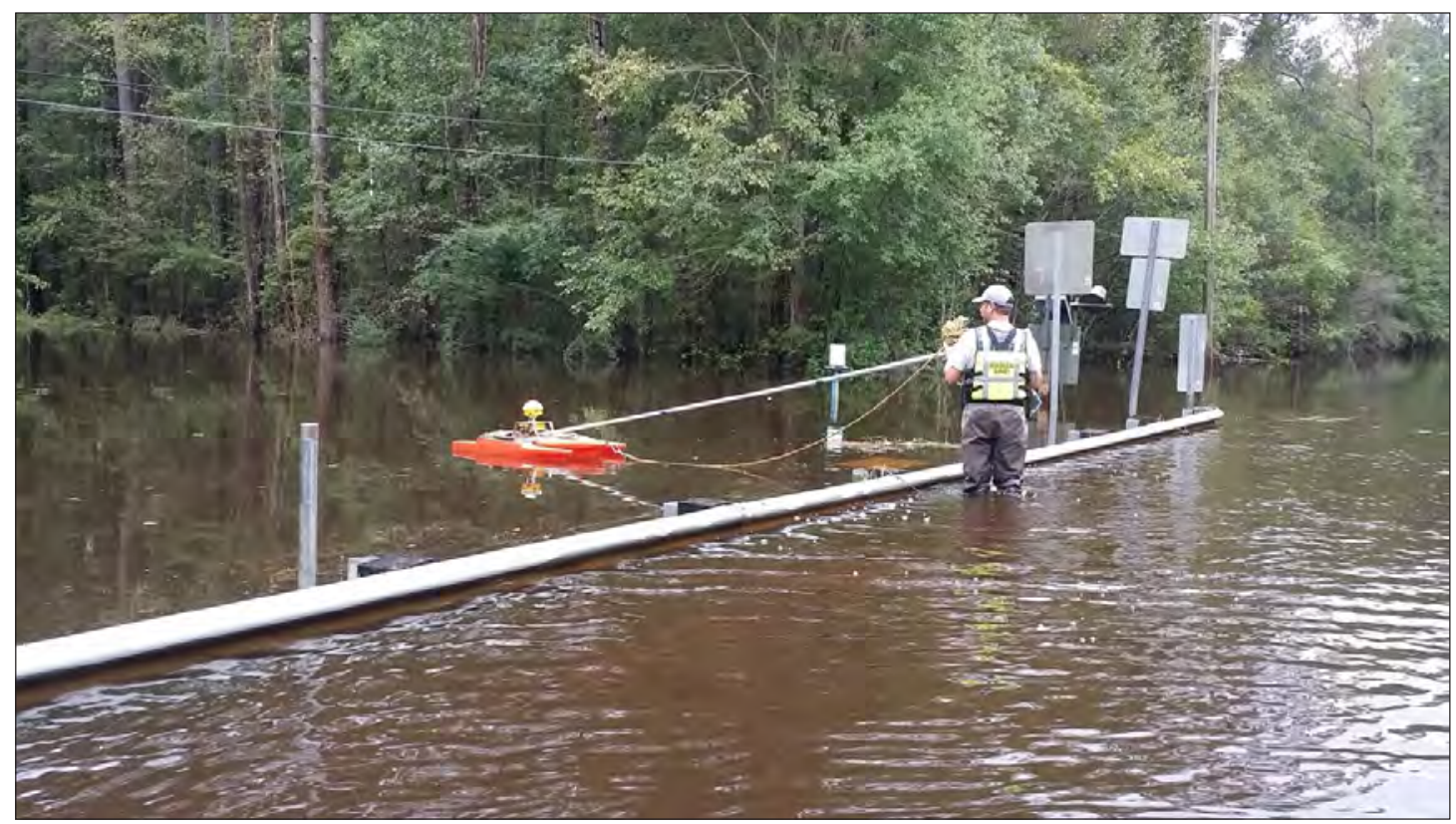

Figure 7. U.S. Geological Survey personnel making a streamflow measurement at station 02110701, Crabtree Swamp at Conway, South Carolina, using an acoustic Doppler current profiler.

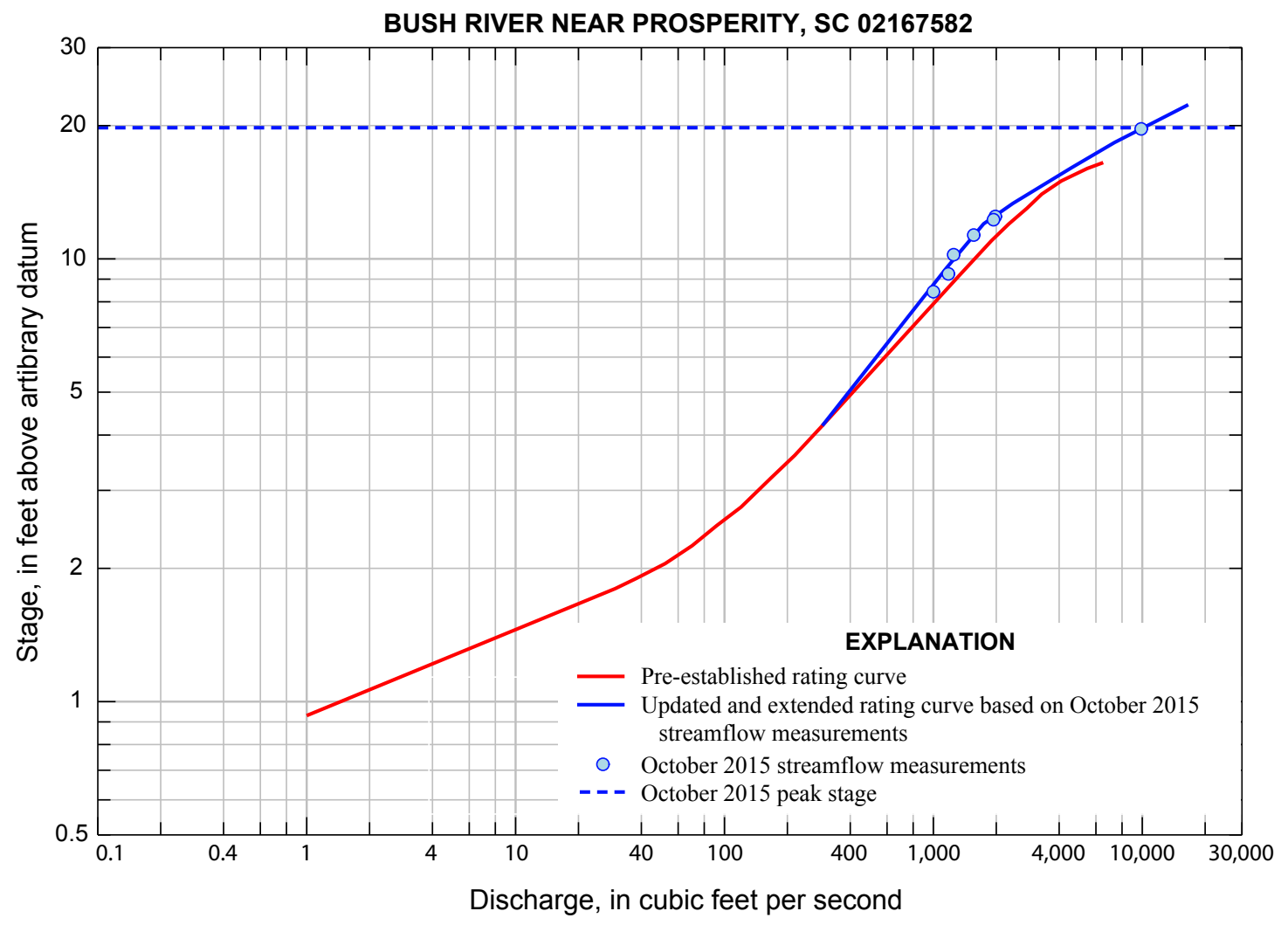

Figure 8. Rating curves developed for use before (red) and after (blue) the October 2015 flood for Bush River near Prosperity, South Carolina (U.S. Geological Survey station 02167582), showing streamflow measurements made during the event. 
field survey. Roughness is subjectively determined on the basis of bed material, cross-section irregularities, depth of flow, vegetation, and channel alignment. The USGS assigns uncertainty/accuracy estimates to each indirect measurement on the basis of the hydraulic and geometry conditions found at each field site (Benson and Dalrymple, 1967; Dalrymple and others, 1967; Hulsing, 1967; Matthai, 1967; Bodhaine, 1968). In other cases, high-water marks are documented for the purpose of recording the depth of the flood waters (fig. 9).

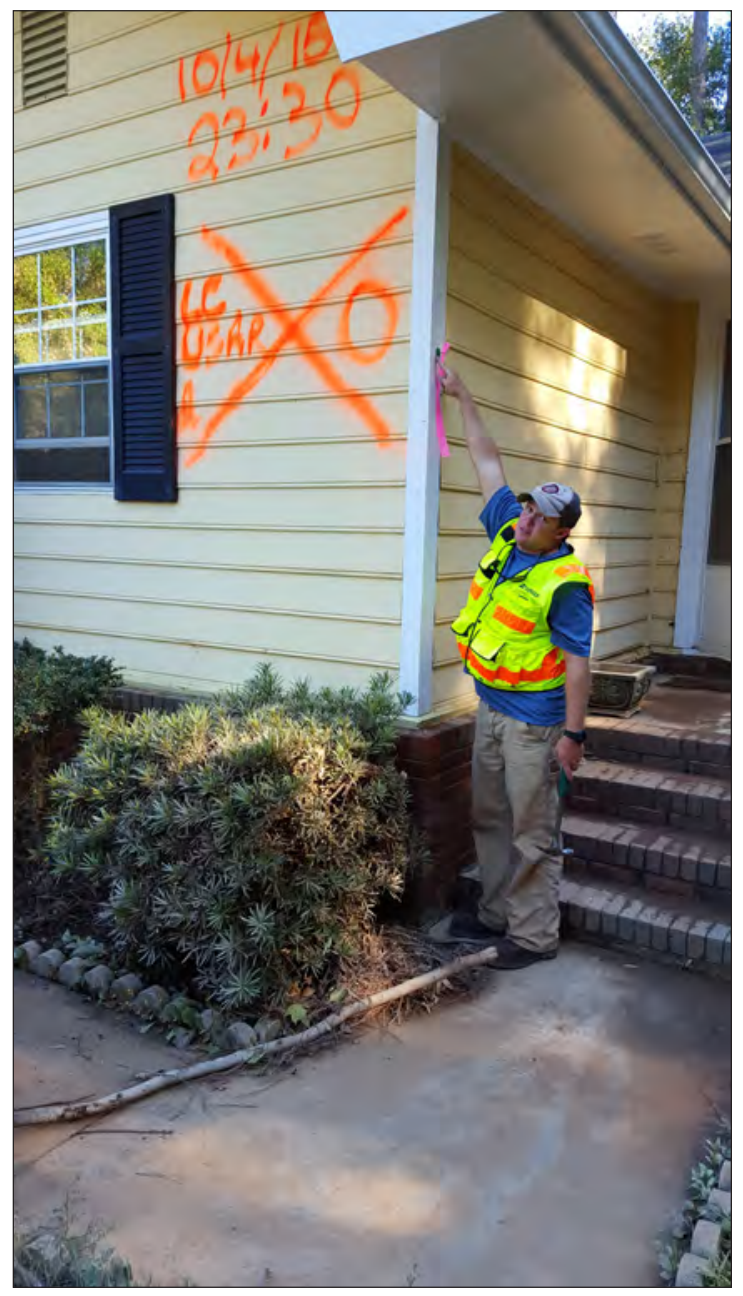

Figure 9. U.S. Geological Survey field crews conducting surveys of high-water marks to document the depth of flood waters in Lexington County, South Carolina, for the October 2015 flood.

\section{Peak Streamflow and Stage}

Peak streamflow and stage during the October 2015 flood for 86 streamgages are listed in table 1 (at the back of the report), and their site locations are shown in figure 6 . The streamgages included in table 1 were chosen because (1) both peak stage and peak streamflow for the October 2015 flood event were monitored at the site, and (2) historic streamflow and (or) stage data were available for comparison. Where the full period of record of peak streamflow is available, comparisons were made on peak streamflow. However, at some sites the peak stage for this event may be lower than a previous peak stage due to backwater conditions, datum changes, or change in the upper end of the rating curve.

The rank for the 2015 peak streamflow at selected streamgages for the period of record is presented in table 1 . If for the previous maximum stage the maximum streamflow was undetermined, the rank was based on the peak stage comparison from the flood of October 2015 instead of the peak streamflow and is indicated as such in the Remarks column of table 1 . Seventeen of the 86 streamgages had new peaks of record. Of the 61 stations with at least 20 years of record, eight had new peaks of record: 02136000, Black River at Kingstree (87 years) (fig. 10); 02136361, Turkey Creek near Maryville (21 years); 02162093, Smith Branch at North Main Street at Columbia (38 years); 02167450, Little River near Silverstreet (24 years); 02167582, Bush River near Prosperity (24 years); 02168504, Saluda River below Lake Murray Dam near Columbia (26 years); 02169570, Gills Creek at Columbia (50 years); and 02175000, Edisto River near Givhans (81 years).

Along with the 17 streamgages that had new peaks of record, an additional 15 streamgages recorded new peaks that ranked in the top 5 for the period of record. For stations with at least 20 years of record, 13 recorded peaks ranked in the top 5 for the period of record.

\section{Comparison of the October 2015 Flood to Past Floods}

In the Pee Dee River Basin, a new period of record peak occurred on October 6, 2015, for station 02136000, Black River at Kingstree, with a stage of $22.65 \mathrm{ft}$ and corresponding streamflow of 83,700 cubic feet per second ( $\mathrm{ft}^{3} / \mathrm{s}$ ) (fig. 10). This was the largest peak in 87 years; the previous maximum peak occurred on June 14, 1973. Annual maximum peak stage data contained in reports of the National Weather Service indicate the October 2015 peak is the largest since 1893. Although not the peak of record, the peak on October 6, 2015, at station 02132000 , Lynches River at Effingham, was the third largest peak for the 88 years of record; the maximum peak of record occurred on September 22, 1945. Annual maximum peak stage data contained in reports of the National 
BLACK RIVER AT KINGSTREE, SC 02136000

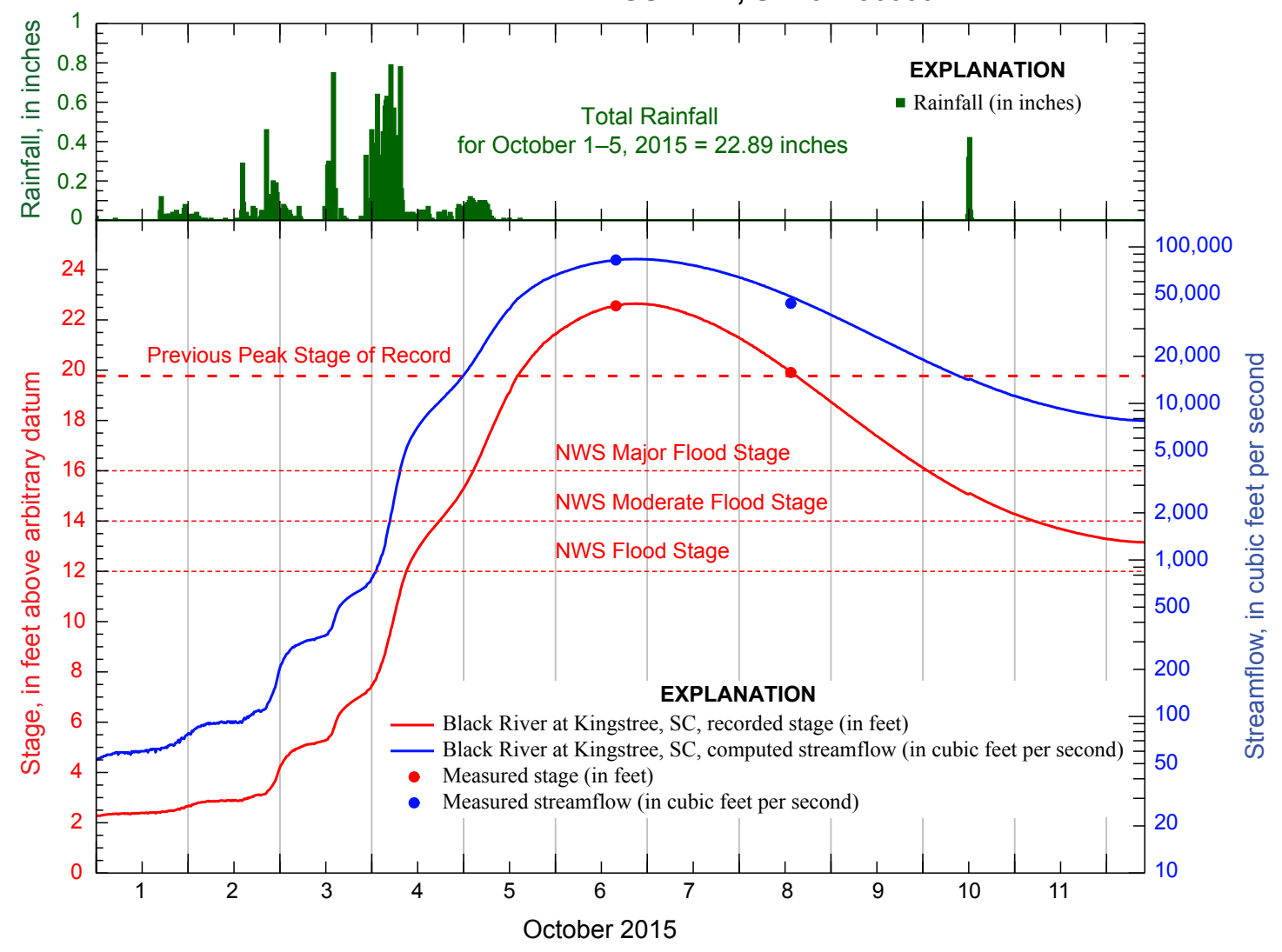

Figure 10. Black River at Kingstree, South Carolina (U.S. Geological Survey station 02136000) stage and streamflow hydrographs and associated rainfall for October 1-11, 2015.

Weather Service indicate the October 2015 peak is the third largest since 1892.

In the Waccamaw River Basin, annual peak stage and streamflow data have been collected at station 02110500, Waccamaw River near Longs, since 1951. For the 2015 flood, the peak occurred on October 6, 2015, and was the second largest peak in 64 years of record. The maximum peak of record occurred on September 22, 1999, and was associated with rainfall from the passage of Hurricane Floyd.

Station 02169500, Congaree River at Columbia, has one of the longest records of annual peak flows of the USGS streamgages in South Carolina, with systematic records of annual peak streamflow from 1892 to present. Additional information for a flood in 1852 is available; therefore, the site is of great value in placing the current flood in context to other historical floods. The Congaree River is formed by the convergence of the Saluda and Broad Rivers at Columbia, SC. The Saluda River is regulated by the Saluda Dam, which was completed in 1929 (Conrads and others, 2008). Low-head dams on the Broad River have regulated low streamflows since the late 1880 s and early 1900 s, but flood flows are essentially unregulated. The Broad River Basin accounts for approximately two-thirds of the drainage area for the Congaree River at Columbia station.
Conrads and others (2008) assessed the impact that the Saluda Dam has had on the flood frequency of flows on the Congaree River and concluded that the 1-percent chance flood (also referred to as the 100-year flood) is likely reduced by about 18 percent due to regulation on the Saluda River. Consequently, comparison of major floods that have occurred on the Congaree River after construction of the Saluda Dam with those prior to the construction of the Saluda Dam provides insightful information with respect to historical floods. The Congaree River at Columbia peaked at $185,000 \mathrm{ft}^{3} / \mathrm{s}$ at a peak stage of $31.8 \mathrm{ft}$ on October 4, 2015. When compared to the historical flood record, this peak ranks eighth out of 123 years of record with the peak of record being $364,000 \mathrm{ft}^{3} / \mathrm{s}$ at a peak stage of $39.8 \mathrm{ft}$ on August 27, 1908. The last flood to exceed the October 2015 peak at the Congaree River at Columbia site occurred on April 8, 1936, when the river peaked at $231,000 \mathrm{ft}^{3} / \mathrm{s}$ at a peak stage of $33.3 \mathrm{ft}$.

For a historical perspective on the floods caused by the heavy rainfall during October 1-5, 2015, a chronology of major floods in South Carolina since 1893 is presented in table 2 (at the back of the report) (U.S. Geological Survey, 1985; http://sc.water.usgs.gov/publications/pdf/ SCFloodsandDroughts1893-2002.pdf; http://www.dnr.sc.gov/ climate/sco/Tropics/hurricane_tracks_affecting_sc.php.) 


\section{Summary}

During October 1-5, 2015, flooding on numerous streams and rivers from the central to the coastal areas of South Carolina resulted in at least 17 fatalities. South Carolina officials have been quoted in media outlets as saying agricultural losses could conservatively be at least $\$ 300$ million, with cleanup costs across the State that could top $\$ 1$ billion. The flooding was the result of large rainfall amounts, including nearly 27 inches of rain in Charleston County. On October 4, 2015, rainfall amounts at the Columbia Metropolitian Airport set a new record for the greatest 1-day rainfall of 6.71 inches, breaking the previous record of 5.79 inches set on July 9, 1959.

Preliminary peak streamflow and stage data, collected by the U.S. Geological Survey (USGS), are documented in this report. New peak streamflow records were set at 17 USGS streamgages, with an additional 15 USGS streamgages having October 2015 peaks that ranked them in the top 5 for the period of record. In the Pee Dee River Basin, a new peak of record was recorded on October 6, 2015, for station 02136000, Black River at Kingstree - the largest peak for the 87 years of record available. Annual maximum peak stage data contained in reports of the National Weather Service indicate the October 2015 peak is the largest since 1893. Although not the peak of record, the peak on October 6, 2015, at station 02132000, Lynches River at Effingham, was the third largest peak for the 88 years of record with the maximum peak of record occurring on September 22, 1945. Annual maximum peak stage data contained in reports of the National Weather Service indicate the October 2015 peak is the third largest since 1892. Peaks of record also were recorded near the city of Columbia at station 02162093, Smith Branch at North Main Street at Columbia, and station 02169570, Gills Creek at Columbia. During the October 2015 flood, U.S. Geological Survey personnel made about 140 streamflow measurements at 86 locations to verify, update, or extend existing rating curves.

\section{References Cited}

Badr, A.W., Wachob, Andrew, and Gellici, J.A., 2004, South Carolina Water Plan (2d ed.): South Carolina Department of Natural Resources, Land, Water and Conservation Division, $120 \mathrm{p}$.

Benson, M.A., and Dalrymple, Tate, 1967, General field and office procedures for indirect discharge measurements: U.S. Geological Survey Techniques of Water-Resources Investigations, book 3, chap. A1, $30 \mathrm{p}$. (Also available at http://pubs.er.usgs.gov/publication/twri03A1.)
Bloxham, W.M., 1979, Low-flow frequency and flow duration of South Carolina streams: South Carolina Water Resources Commission Report No. 11, 48 p.

Bodhaine, G.L., 1968, Measurement of peak discharge at culverts by indirect methods: U.S. Geological Survey Techniques of Water-Resources Investigations, book 3, chap. A3, 60 p. (Also available at http://pubs.usgs.gov/twri/twri3-a3/.)

Conrads, P.A., Feaster, T.D., and Harrelson, L.G., 2008, The effects of the Saluda Dam on the surface-water and groundwater hydrology of the Congaree National Park flood plain, South Carolina: U.S. Geological Survey Scientific Investigations Report 2008-5170, 58 p. (Also available at http://pubs.water.usgs.gov/sir2008-5170.)

Cooke, C.W., 1936, Geology of the Coastal Plain of South Carolina: U.S. Geological Survey Bulletin 867, 196 p.

Dalrymple, Tate, and Benson, M.A., 1967, Measurement of peak discharge by the slope-area method: U.S. Geological Survey Techniques of Water-Resources Investigations, book 3, chap. A2, 12 p. (Also available at http://pubs.usgs. gov/twri/twri3-a2/.)

Hulsing, Harry, 1967, Measurement of peak discharge at dams by indirect methods: U.S. Geological Survey Techniques of Water-Resources Investigations, book 3, chap. A5, 29 p. (Also available at http://pubs.usgs.gov/twri/twri3-a5/.)

Lurry, D.L., 2011, How does a U.S. Geological Survey streamgage work?: U.S. Geological Survey Fact Sheet 2011-3001, 2 p. (Also available at http://pubs.usgs.gov/ fs/2011/3001/.)

Matthai, H.F., 1967, Measurement of peak discharge at width contractions by indirect methods: U.S. Geological Survey Techniques of Water-Resources Investigations, book 3 , chap. A4, 44 p. (Also available at http://pubs.usgs.gov/twri/ twri3-a4/.)

National Oceanic and Atmospheric Administration, 2015, Climate Data Online, accessed October 8, 2015, at http://www.ncdc.noaa.gov/climatenormals/clim60/states/ Clim_SC_01.pdf.

Omernik, J.M., 1987, Ecoregions of the conterminous United States: Annals of the Association of American Geographers, v. 77, no. 1, p. 118-125, map scale 1:7,500,000.

Turnipseed, D.P., and Sauer, V.B., 2010, Discharge measurements at gaging stations: U.S. Geological Survey Techniques and Methods book 3, chap. A8, 87 p. (Also available at http://pubs.usgs.gov/tm/tm3-a8/.)

U.S. Geological Survey, 1985, National Water Summary 1988-89, Hydrologic events and floods and droughts: U.S. Geological Survey Water-Supply Paper 2375, 589 p. 
Tables

11

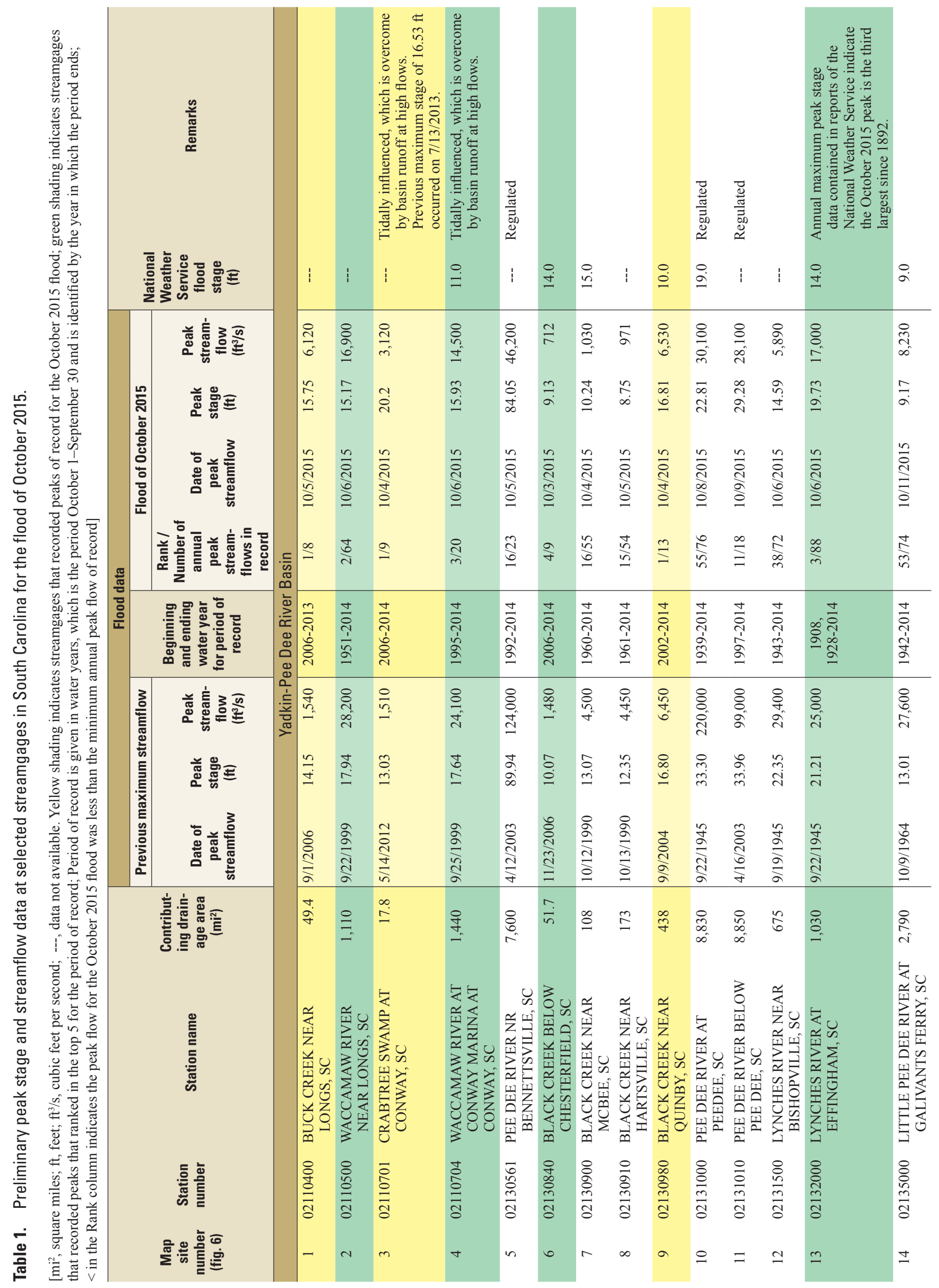




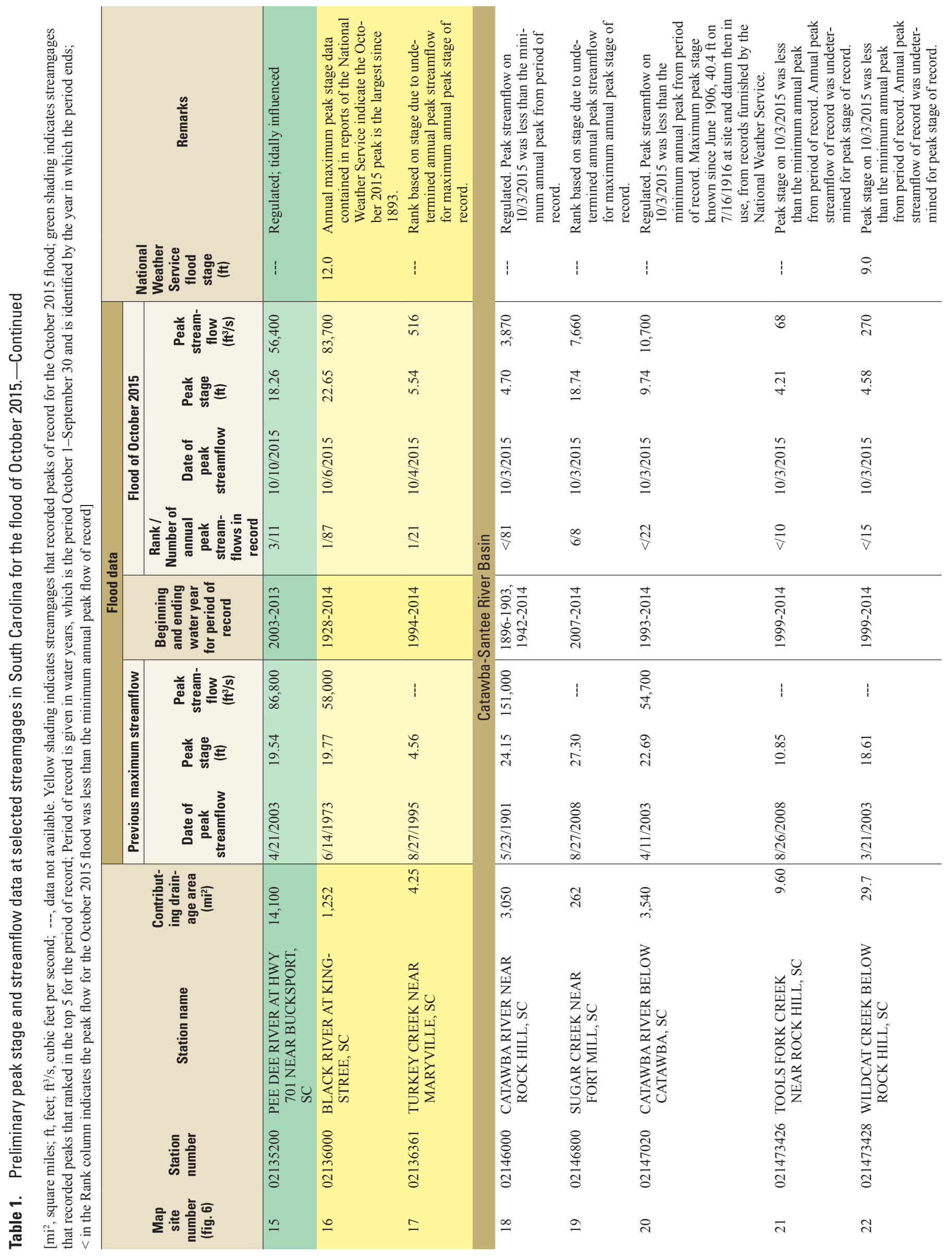




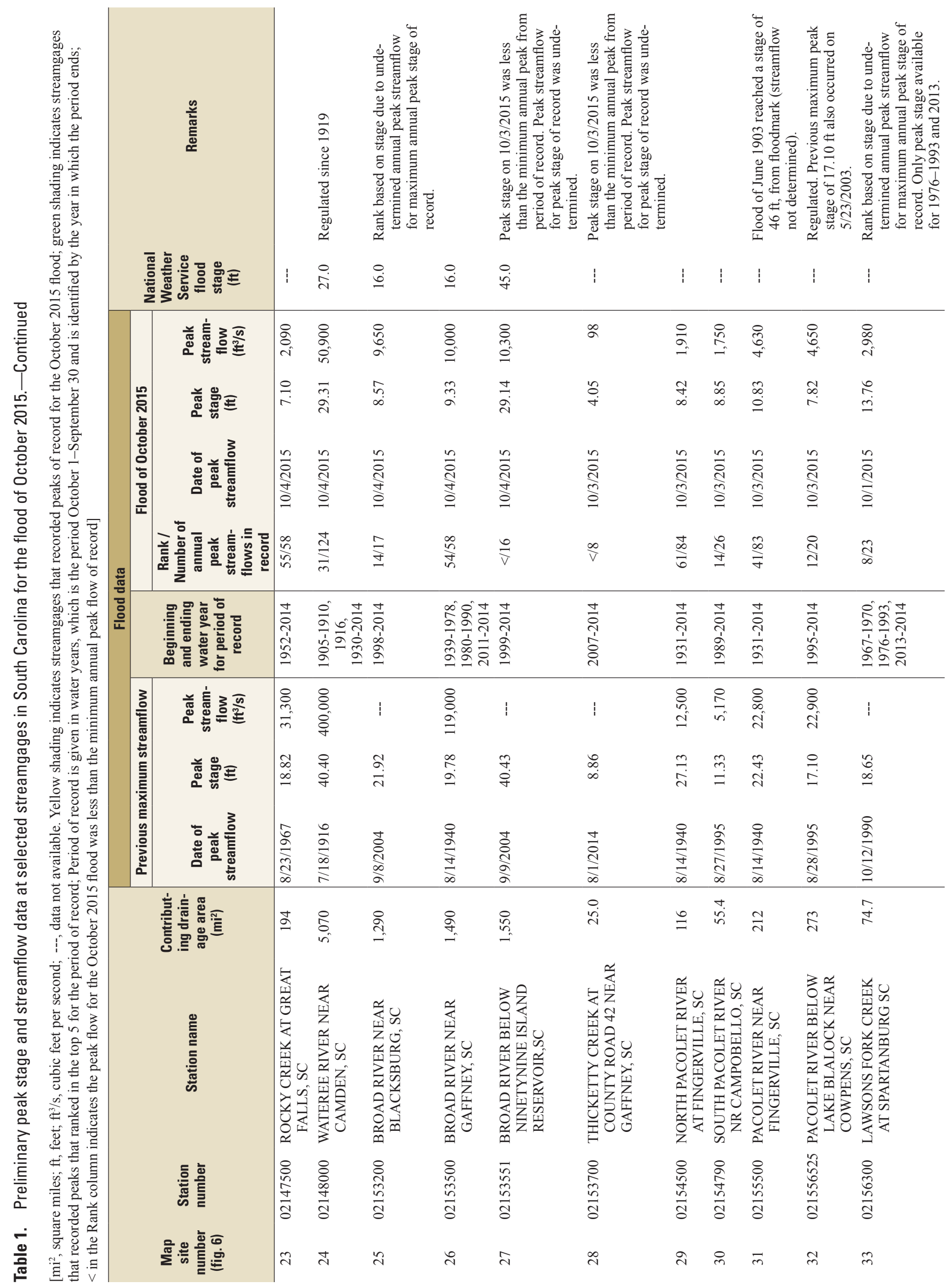




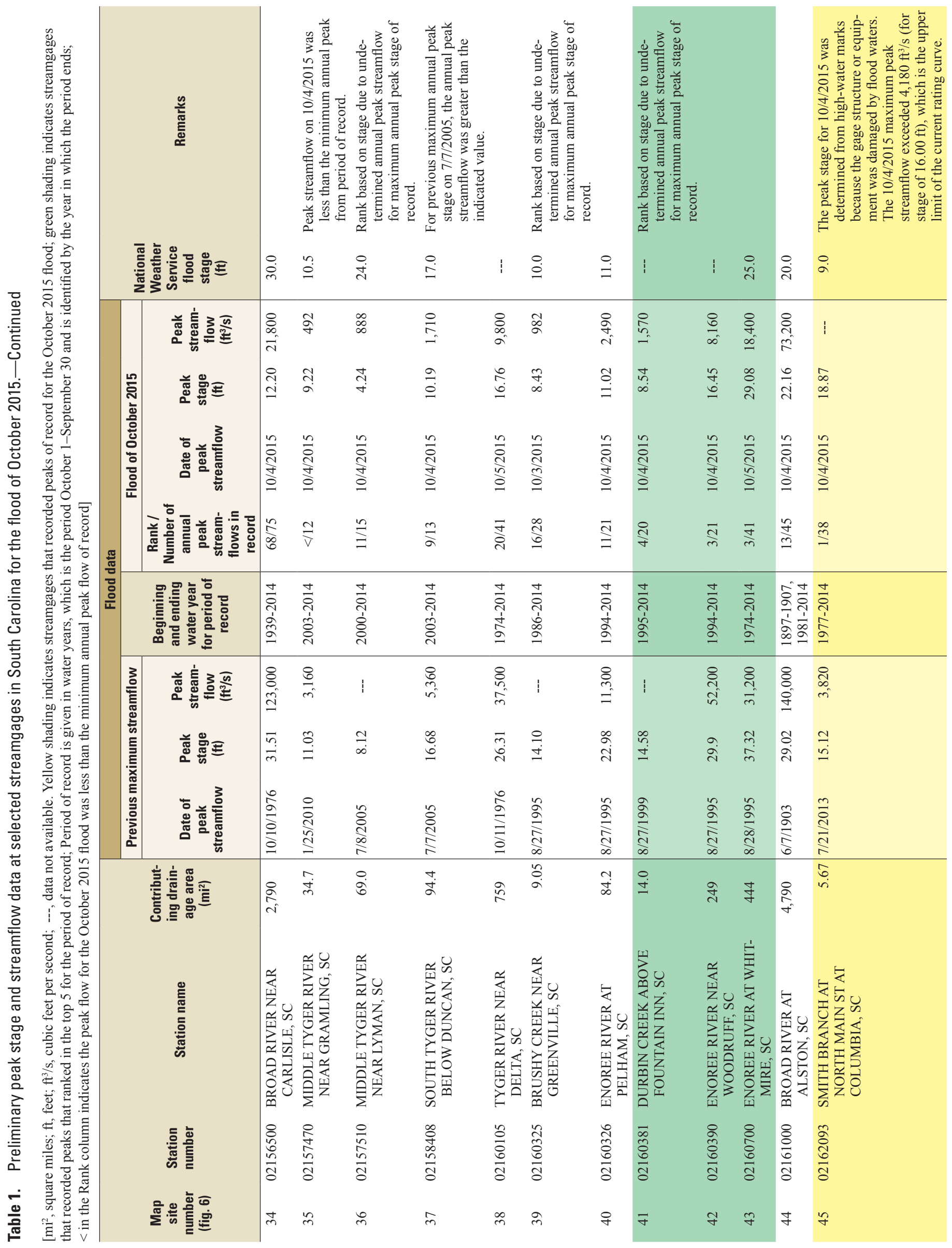




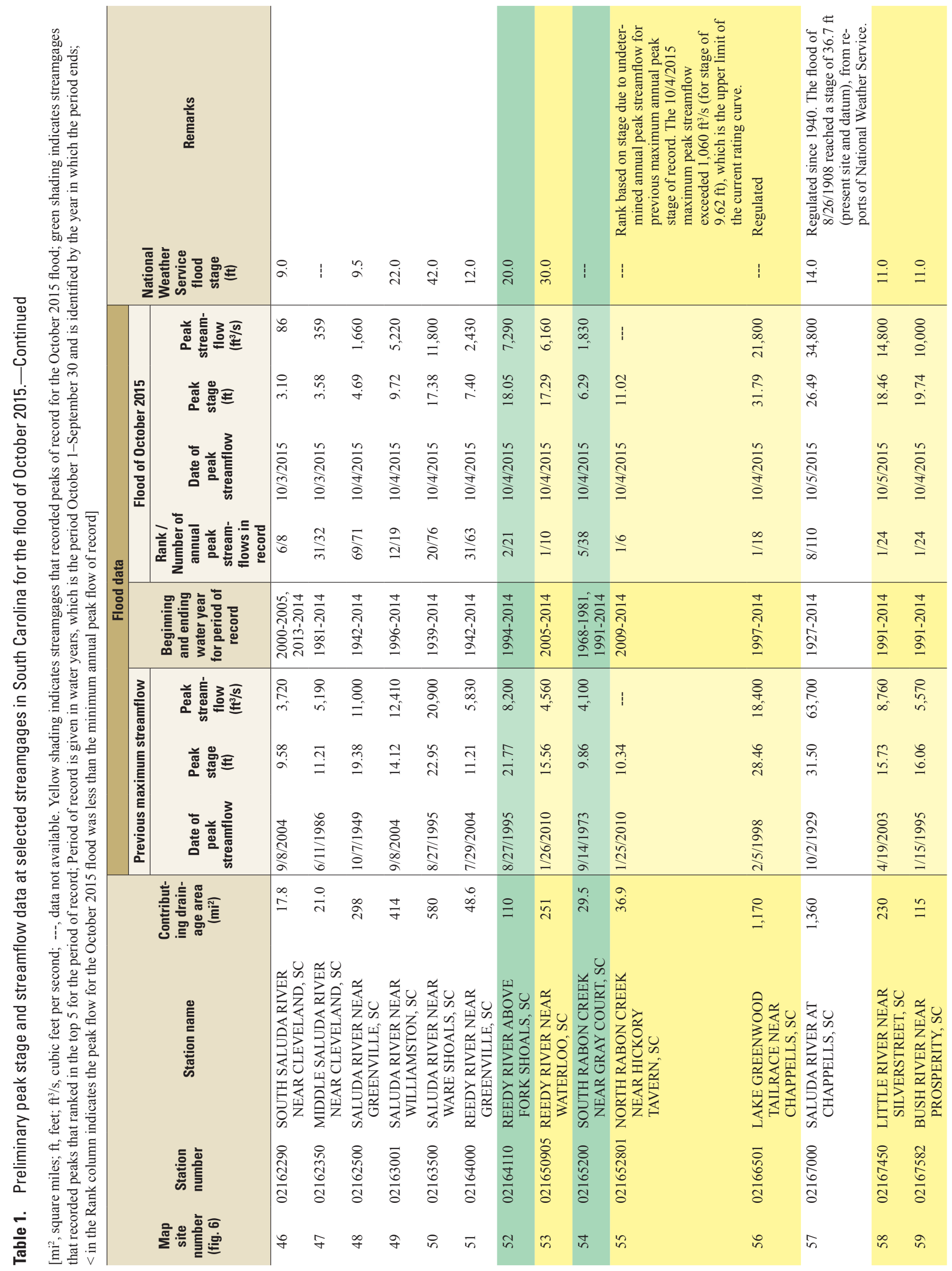




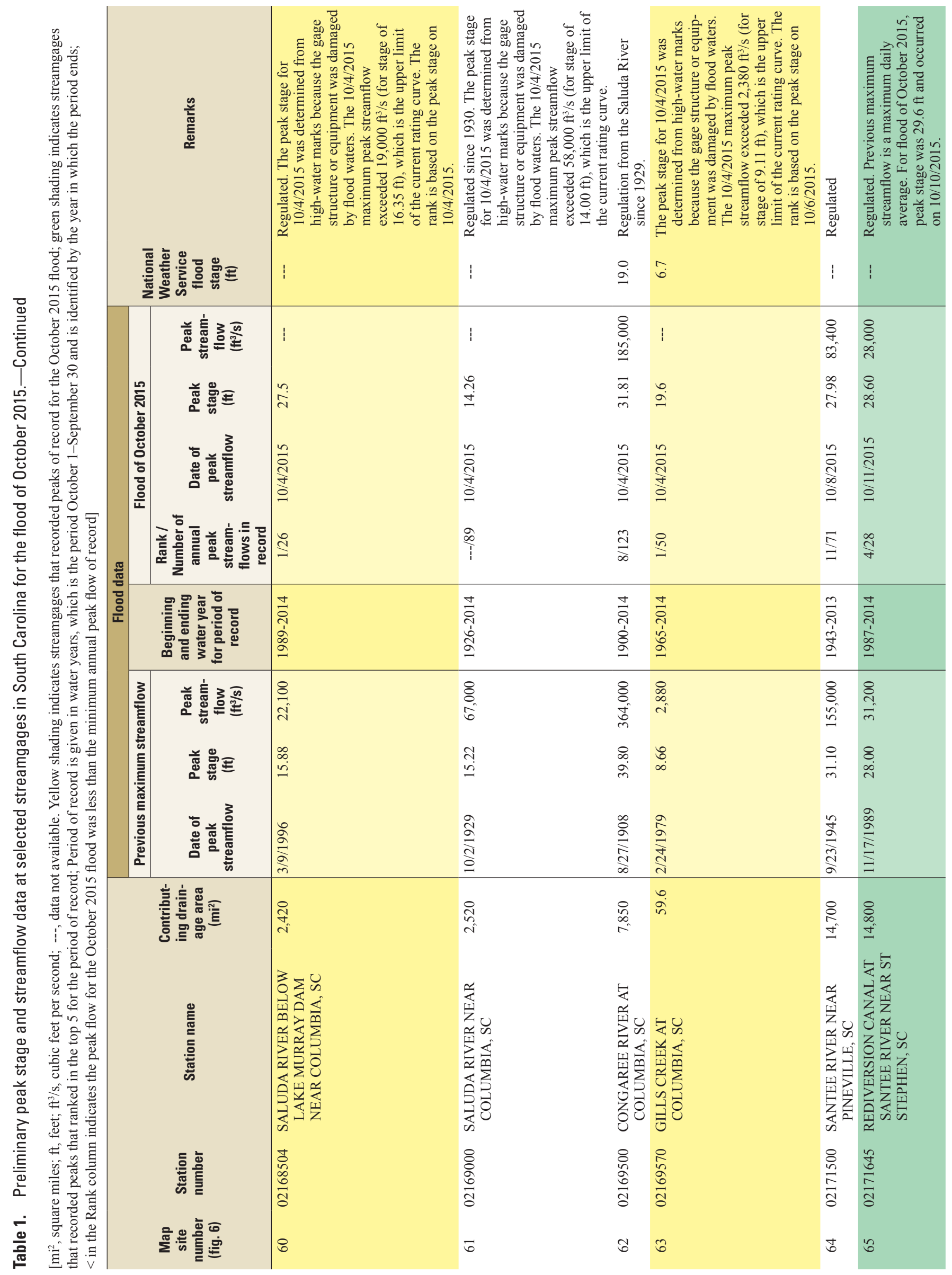




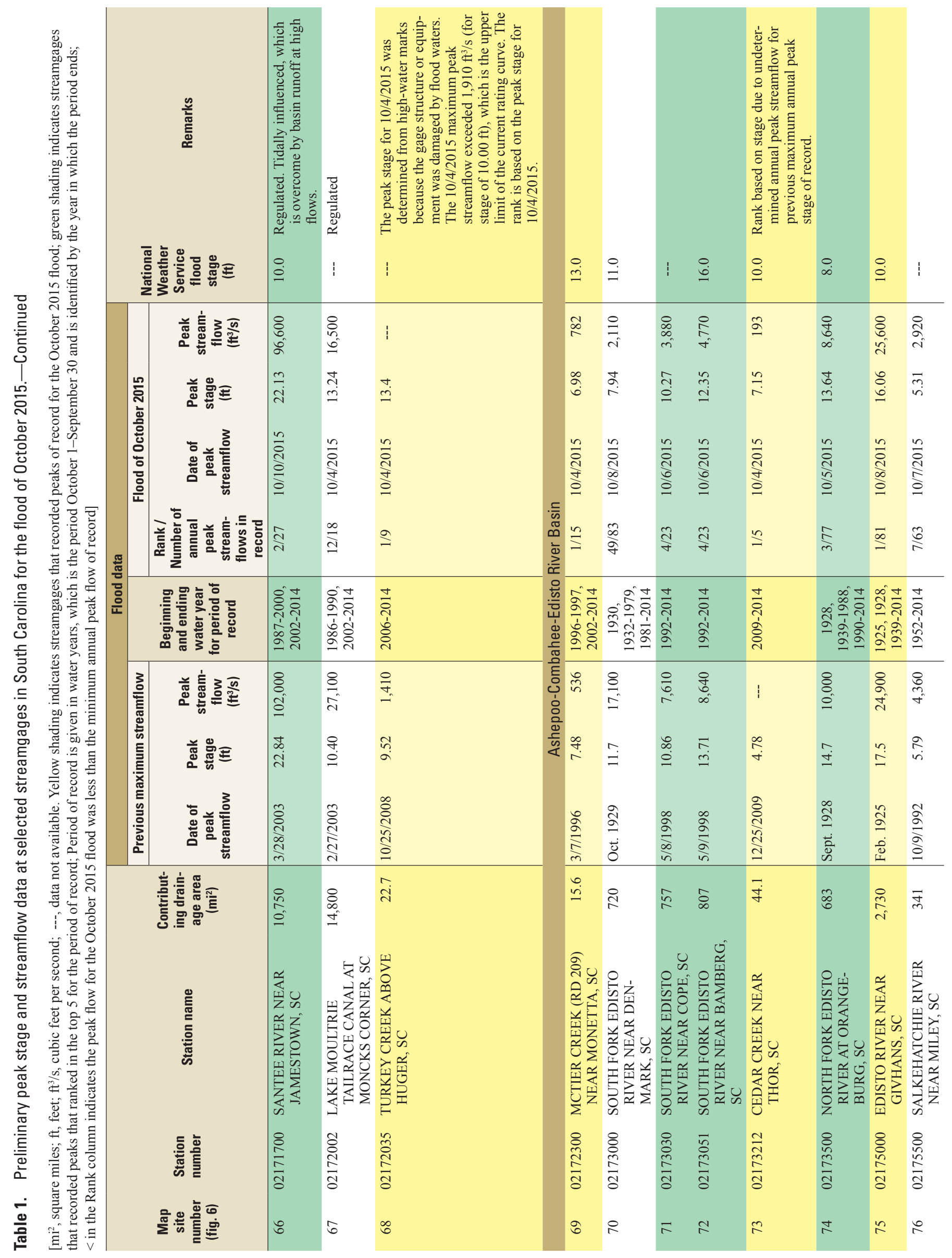




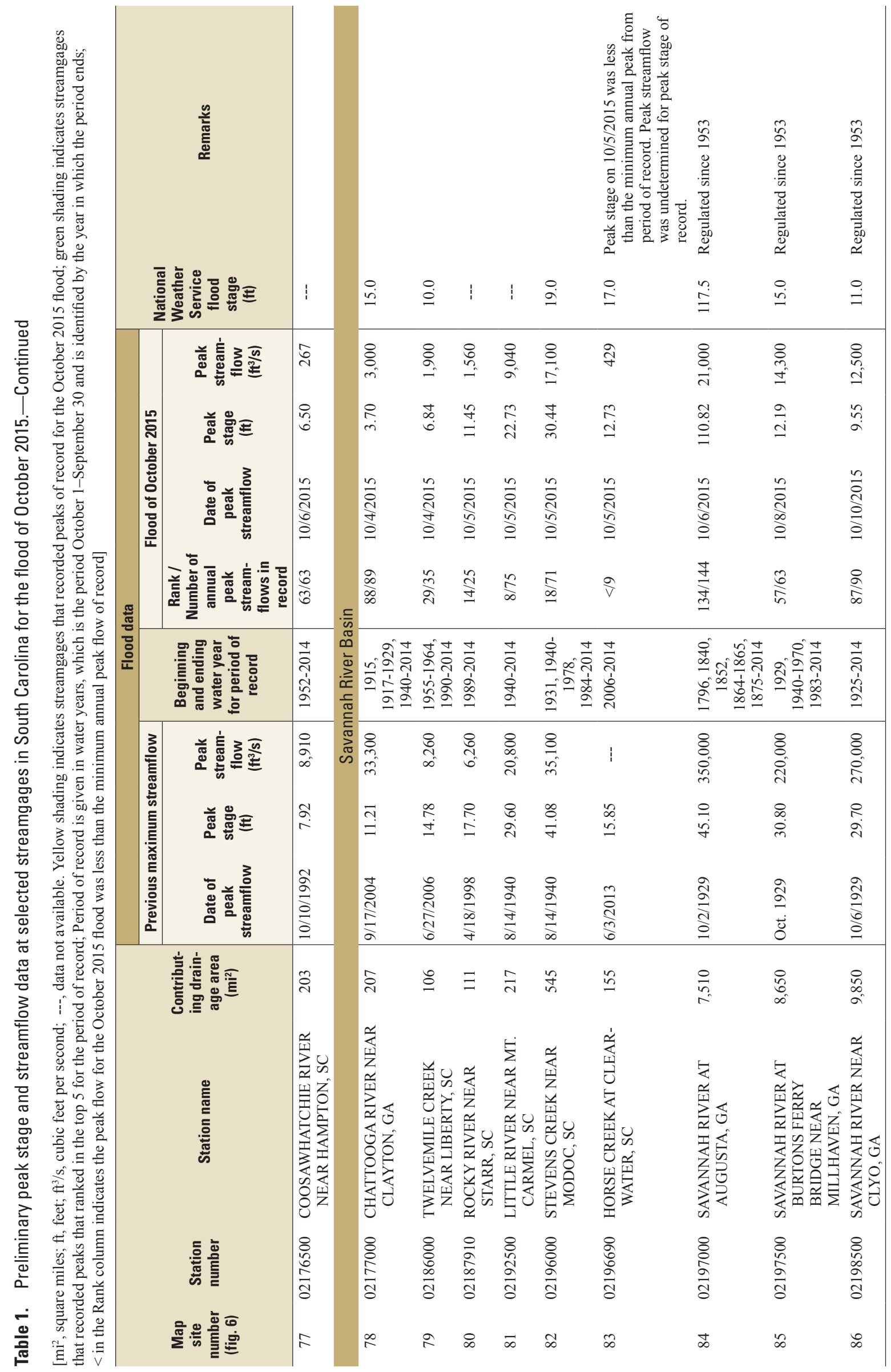


Table 2. Chronology of major and other memorable floods in South Carolina since 1893.

[From U.S. Geological Survey, 1985; http://sc.water.usgs.gov/publications/pdf/SCFloodsandDroughts1893-2002.pdf; http://www.dnr.sc.gov/climate/sco/Tropics/hurricane_tracks_affecting_sc.php. mph, miles per hour]

\begin{tabular}{|c|c|c|}
\hline Date & Area affected & Remarks \\
\hline Aug. 27, 1893 & Southern coast of South Carolina & $\begin{array}{l}\text { North-northeast through South Carolina Midlands. Winds } 96-120 \mathrm{mph} \text {; tre- } \\
\text { mendous storm surge; major damage; moved north near Columbia, then } \\
\text { northeast. Deaths, } 2,000 \text {; damage, } \$ 10 \text { million. }\end{array}$ \\
\hline Aug. 26-30, 1908 & Statewide & Most extensive flood in State; rainfall, 12 inches in 24 hours at Anderson. \\
\hline July 18,1916 & Eastern two-thirds of State & $\begin{array}{l}\text { Record rainfall, } 13 \text { inches in } 24 \text { hours at Effingham; damage, } \\
\$ 10-11 \text { million. }\end{array}$ \\
\hline Sept. 21-24, 1928 & $\begin{array}{l}\text { Lower Pee Dee River Basin and southern } \\
\text { South Carolina }\end{array}$ & $\begin{array}{l}\text { Flooding was severe. Rainfall 10-12 inches. Deaths, 5; damage, } \\
\$ 4-6 \text { million. }\end{array}$ \\
\hline Oct. 2,1929 & Savannah and Santee River Basins & $\begin{array}{l}\text { Entered Aiken as extratropical storm; intense rains on saturated soil caused } \\
\text { severe flooding. }\end{array}$ \\
\hline Aug. 11-19, 1940 & Statewide & $\begin{array}{l}\text { Hurricane related flooding. Deaths, about 34; property and crop damage, } \\
\$ 10 \text { million. }\end{array}$ \\
\hline Sept. 29-30, 1959 & Eastern, southern, and central South Carolina & $\begin{array}{l}\text { Hurricane Gracie. Winds } 140 \mathrm{mph} \text { at landfall. Six foot storm surge. Rain- } \\
\text { fall, 6-8 inches. Deaths, } 7 \text {; Excessive property damage along the coast as } \\
\text { well as heavy crop damage, } \$ 20 \text { million. }\end{array}$ \\
\hline Nov. 1, 1969 & Coastal, northwest corner of the State & Rainfall, 13.6 inches on Edisto Island. Deaths, 1; flood damage to homes. \\
\hline Sept. 14, 1973 & $\begin{array}{l}\text { Northwestern South Carolina, Savannah and } \\
\text { Santee River Basins }\end{array}$ & $\begin{array}{l}\text { Major flash flood in Laurens. Saluda River at Ware Shoals had highest crest } \\
\text { since } 1929 \text { flood. Damage, \$4-6 million. }\end{array}$ \\
\hline Aug. 19, 1981 & Lower Pee Dee River Basin & $\begin{array}{l}\text { Hurricane Dennis, greater than } 6 \text { inches of rain caused significant flood } \\
\text { damage in low-lying areas. Greatest flood on upper Waccamaw River } \\
\text { since } 1945 .\end{array}$ \\
\hline Sept. 21, 1989 & Eastern two-thirds of State & $\begin{array}{l}\text { Hurricane Hugo made landfall at Isle of Palms, S.C. Winds } 140 \mathrm{mph} \text {. } \\
\text { Gusts } 160 \mathrm{mph} \text {. Costliest storm in South Carolina's history. Deaths, } 35 \text {; } \\
\text { damage, more than } \$ 6 \text { billion. Storm surge over } 20 \text { feet. Severe inland } \\
\text { damage as winds gusted to } 109 \mathrm{mph} \text { at Sumter, S.C. }\end{array}$ \\
\hline Aug. 25-29, 1995 & Northwestern Piedmont South Carolina & $\begin{array}{l}\text { Tropical Storm Jerry tracked through the upstate of South Carolina, causing } \\
\text { flash floods and dumping } 8-10 \text { inches of rain in about an } 8 \text {-hour period. } \\
\text { Some rain totals exceeded } 20 \text { inches. Several large dams broke causing } \\
\text { flooding across the State. Estimated } \$ 4-5 \text { million worth of damage to } \\
\text { roads and bridges. }\end{array}$ \\
\hline Sept. 16, 1999 & Waccamaw and Lower Pee Dee River Basins & $\begin{array}{l}\text { Hurricane Floyd: Rainfall was heavy along coastal counties; } 12 \text { inches in } \\
\text { Georgetown County; } 18 \text { inches in eastern Horry County. The heavy rains } \\
\text { caused flooding to many roads and buildings. Waves were reported to be } \\
15 \text { feet at the pier at Cherry Grove where damage was the greatest. }\end{array}$ \\
\hline
\end{tabular}



Manuscript was approved for publication on October 16, 2015.

For more information concerning this publication contact Toby Feaster

South Atlantic Water Science Center

U.S. Geological Survey

720 Gracern Road

Stephenson Center, Suite 129

Columbia, SC 29210

(803) 750-6100

Or visit the South Atlantic Water Science Center Web site at http://sc.water.usgs.gov

Prepared by the USGS Science Publishing Network, Raleigh Publishing Service Center 


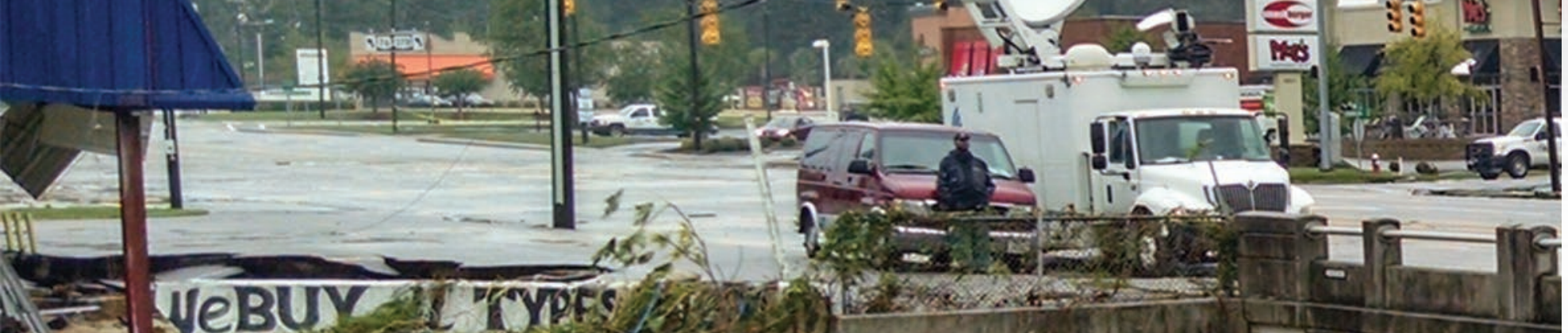

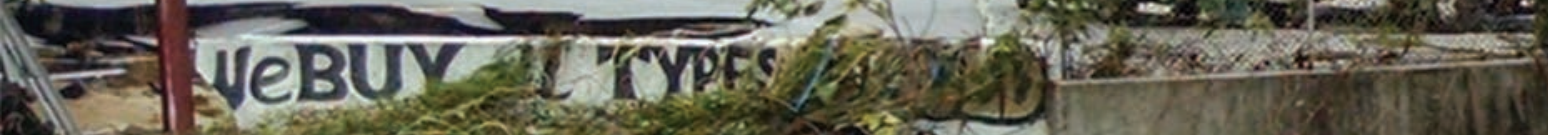

M.
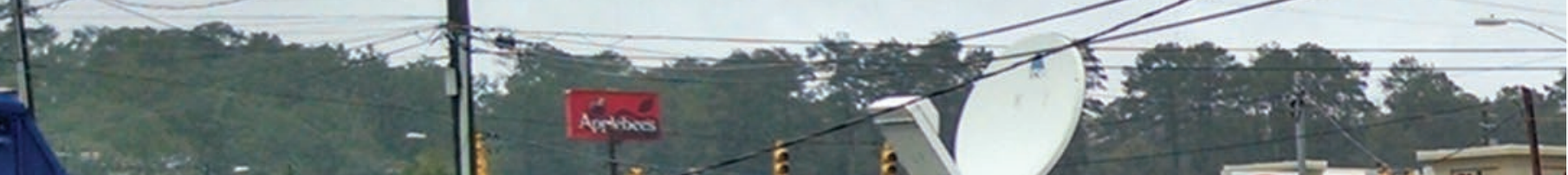

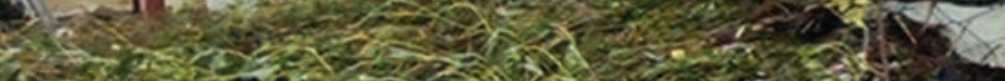

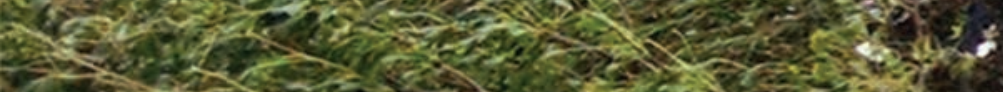

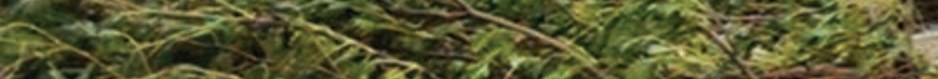

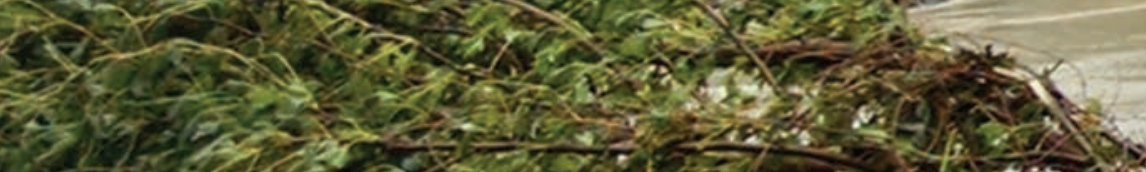

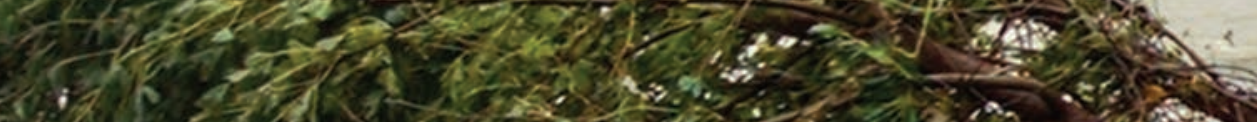

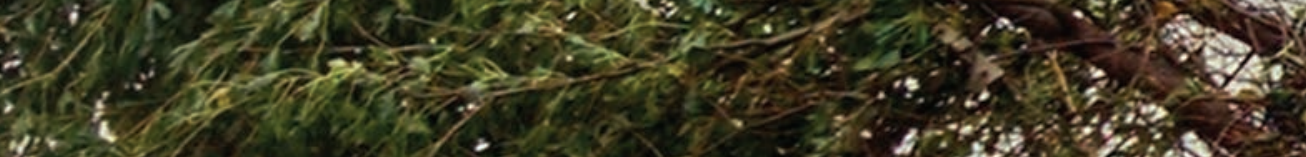

(5)

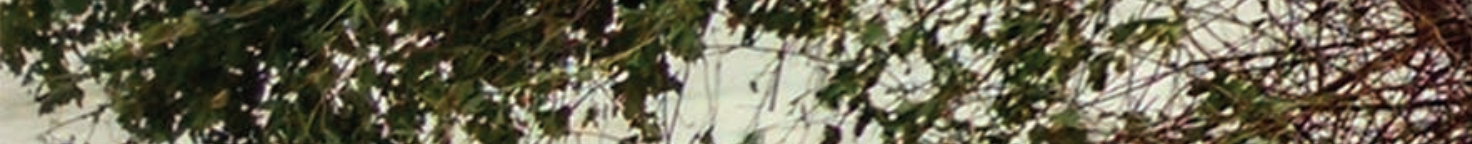

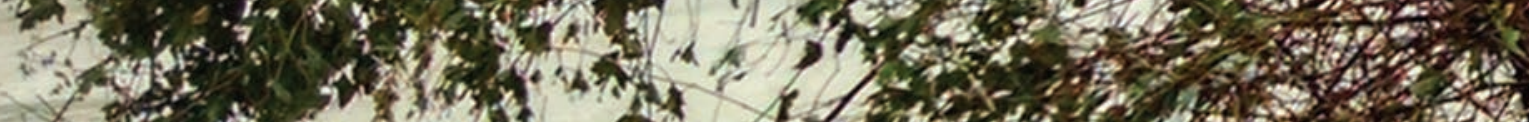

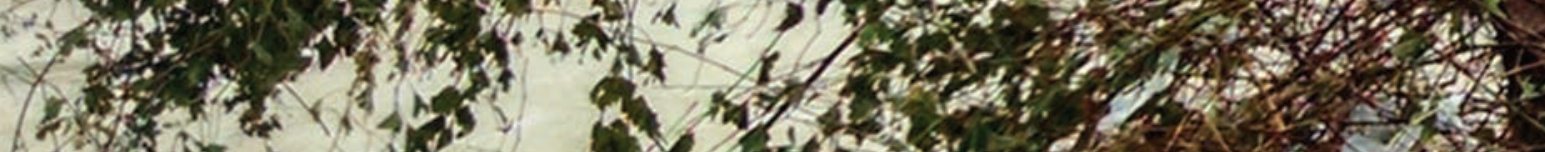

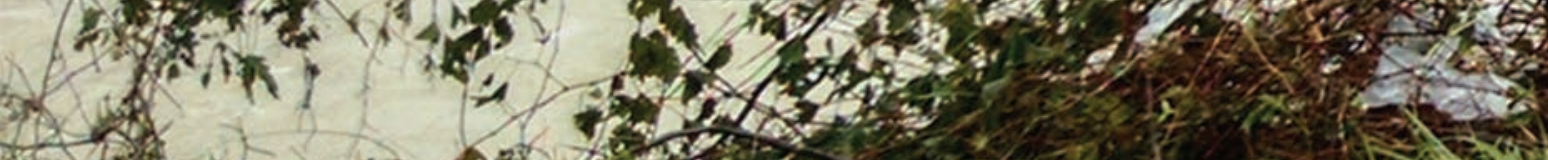

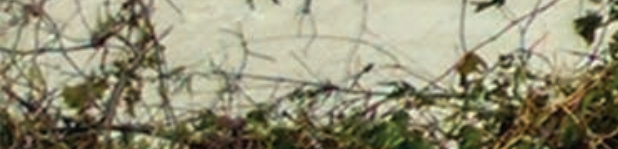
te 